\title{
Corrosion risk assessment of structural concrete with coarse crushed concrete aggregate
}

\author{
Wayne Dodds MEng (Hons) \\ Centre for Innovative and Collaborative Construction Engineering, \\ School of Architecture, Building and Civil Engineering, Loughborough \\ University, Loughborough, UK; AECOM, Birmingham, UK \\ (corresponding author: Dodds@aecom.com) \\ Chris Goodier BEng (Hons), PhD \\ Centre for Innovative and Collaborative Construction Engineering, \\ School of Architecture, Building and Civil Engineering, Loughborough \\ University, Loughborough, UK
}

\author{
Christian Christodoulou MEng (Hons), EngD \\ AECOM, Birmingham, UK \\ Simon Austin BSC (Hons), PhD \\ Centre for Innovative and Collaborative Construction Engineering, \\ School of Architecture, Building and Civil Engineering, Loughborough \\ University, Loughborough, UK \\ David Dunne BEng (Hons), PhD \\ AECOM, Birmingham, UK
}

Crushed concrete aggregates (CCA) are an increasingly popular replacement for natural aggregates (NA) in structural concrete due to industry demands for more recycled, low carbon footprint and responsibly sourced materials. There is uncertainty regarding chloride-ion ingress, which can ultimately cause deterioration of reinforced concrete. This is reflected in European and British concrete design standards, which currently exclude CCA in chloride environments. Structural concretes with up to $60 \%$ coarse CCA (and CEM I, CEM II/B-V and CEM III/A binders) were exposed to aggressive chloride environments and monitored with electrochemical techniques and subsequent destructive testing to determine their risk of corrosion initiation. The results showed that CEM II/B-V and CEM III/A concretes with up to $60 \%$ coarse CCA outperformed the control CEM I concrete with $100 \%$ NA, and had a lower risk of corrosion initiation. It is recommended that further monitoring is required over longer periods to determine the corrosion-initiation risk. Supplementary cementitious materials had a beneficial effect on the chloride-ion ingress resistance, significantly increased the predicted time to corrosion initiation beyond the 50-year design life and largely outweighed any observed detrimental effects from an increased coarse CCA content, suggesting that limitations imposed by existing design standards are conservative.

\section{Introduction}

The recycling of demolition concrete is increasingly important in the construction industry, particularly with the move towards a more sustainable way of sourcing materials (Defra, 2015; NFDC, personal communication, 2016; Wrap, 2015).

In the UK, a high proportion of demolition concrete, known as crushed concrete aggregate (CCA) and formerly referred to as recycled concrete aggregate, is utilised as general fill, subbase material or within low-grade concrete (Barritt, 2015). Certain situations, however, may arise where CCA may be a suitable replacement material for structural concrete, such as for a specific project/client requirement, for improved project sustainability credentials, where a good quality, consistent source of CCA is available on site and/or where there is a short supply of natural aggregates (NA) (Filho et al., 2013; Hassan et al., 2016; Yehualaw and Woldesenbet, 2016). Chloride-ion ingress is the most common cause of early deterioration of reinforced concrete (RC) when de-icing salts are applied to highway structures during routine winter operational activities (NACE International, 2012). There is limited research on the effect of coarse CCA on the longevity of RC structures exposed to aggressive chloride environments, particularly the risk of corrosion initiation during its service life; hence, the use of coarse CCA is limited for structural applications (BSI, 2013; BSI, 2015a, 2015b). Furthermore, it is not evident whether higher replacement levels of NA produce structural concretes with the necessary durability. Thus, further research is required to determine the effect of coarse CCA on the risk of corrosion initiation before it can be accepted as a replacement material in higher-value applications.

This study therefore investigated the effects of coarse CCA on the risk of corrosion initiation, the predicted time to corrosion initiation and the depth of chloride-ion ingress when exposed to aggressive chloride environments, to encourage the appropriate use of coarse CCA in structural concrete.

\section{Background information}

2.1 Corrosion risk assessment of structural concrete Chloride-induced corrosion is an electrochemical process that occurs when chloride ions penetrate the concrete cover and react with the passive protective film at the surface of the 
reinforcing steel, resulting in its depassivation (Glass et al., 2000; Kropp, 1995). A 'critical' or 'threshold' chloride-ion concentration is often discussed when attempting to determine the point at which the passive layer breaks down; there is some debate, however, regarding the magnitude of this concentration. The most common value published for free chlorideion content is $0.6 \%$ by mass of cement, with $0.4 \%$ being reported as the minimum (Alonso and Sanchez, 2009; Angst et al., 2009; CS, 2004a; Kropp, 1995). Once steel is exposed to chloride ions, corrosion can aggressively propagate as 'pitting' occurs, producing further acidity from corrosion products (Bertolini et al., 2004; Glass et al., 2007). Localised anodic areas exist at the location of the pits and the surrounding reinforcement becomes cathodic (Figure 1). The process is further accelerated as chloride ions migrate towards the positively charged anodic region (Bertolini et al., 2004; Claisse, 2014).

Non-destructive testing, such as half-cell potential surveys and surface resistivity tests, are well-established methods of

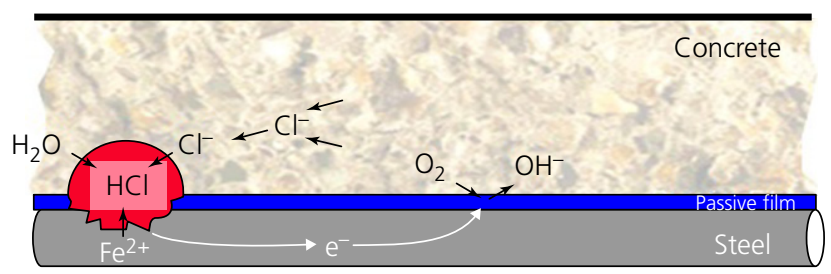

Figure 1. Electrochemical process of chloride-induced corrosion (Glass et al., 2006) assessing the corrosion risk of structural concrete (Assouli et al., 2008). These methods can be used in combination to provide an overall assessment of the risk of corrosion initiation (CS, 2004a).

Half-cell potentials are interpreted following the American Society for Testing and Materials (ASTM) recommendations in Table 1 for saturated copper/copper sulfate $\left(\mathrm{Cu} / \mathrm{CuSO}_{4}\right)$ and silver/silver chloride $(\mathrm{Ag} / \mathrm{AgCl} / 0.5 \mathrm{M} \mathrm{KCl}$ (potassium chloride)) reference electrodes (ASTM, 2009).

Surface-resistivity tests can provide an indication of the microstructure of concrete as a measure of the flow of ions between the anodic and cathodic regions (Broomfield and Millard, 2002; Goodier et al., 2015). The results are commonly interpreted according to the recommendations in Table 2. Both sources indicate that a surface resistivity above $20 \mathrm{k} \Omega \mathrm{cm}$ is associated with a low corrosion rate and chloride-ion penetration.

There are limitations to both methods as the results can be affected by the ambient relative humidity $(\mathrm{RH})$, temperature, $\mathrm{pH}$ value of the concrete pore solution and oxygen availability (Angst and Elsener, 2014; Assouli et al., 2008; CS, 2004a; Holmes et al., 2011).

When there is probable risk of corrosion initiation, intrusive testing can be undertaken to establish the depth of chloride-ion penetration and subsequent corrosion risk. A common approach involves the measurement of chloride-ion concentration by silver nitrate potentiometric titration (BSI, 2015c) of drilled concrete dust samples (Castellote and Andrade, 2001; CS, 2004a). The results are often interpreted by the Concrete

Table 1. Interpretation of half-cell potential surveys (ASTM, 2009)

$\begin{array}{lcl}\begin{array}{l}\text { Voltage against copper/ } \\ \text { copper sulfate: } \mathbf{~} \mathbf{V}\end{array} & \begin{array}{c}\text { Voltage against silver/silver chloride / } \\ \mathbf{0 \cdot 5} \mathbf{~ M} \text { potassium chloride: } \mathbf{~ m V}\end{array} & \begin{array}{l}\text { Interpretation } \\ \hline>-200\end{array} \\ <-200 \text { and }>-350 & >-134 & \text { Greater than } 90 \% \text { probability that no corrosion activity is occurring } \\ <-350 & <-134 \text { and }>-284 & \text { Uncertain corrosion activity } \\ & <-284 & \text { Greater than } 90 \% \text { probability that corrosion activity is occurring }\end{array}$

Table 2. Interpretation of four-point Wenner probe readings

\begin{tabular}{llll}
\hline Concrete Society Technical Report $\mathbf{6 0}$ (CS, 2004a) & & Aashto T358 (Aashto, 2015) \\
\cline { 2 - 4 } Resistivity: $\mathrm{k} \Omega \mathrm{cm}$ & Interpretation & Resistivity: $\mathrm{k} \Omega \mathrm{cm}$ & Interpretation \\
\hline$<5$ & Very high corrosion rate & $<12$ & High chloride-ion penetration \\
$5-10$ & High corrosion rate & $12-21$ & Moderate chloride-ion penetration \\
$10-20$ & Low to moderate corrosion rate & $21-37$ & Low chloride-ion penetration \\
$>20$ & Low corrosion rate & $37-254$ & Very low chloride-ion penetration \\
- & - & $>254$ & Negligible chloride-ion penetration
\end{tabular}


Table 3. Interpretation of chloride-ion concentration (CS, 2004a)

\begin{tabular}{ll}
$\begin{array}{l}\text { Threshold level by } \\
\text { mass of cement: \% }\end{array}$ & Interpretation \\
\hline$>1.0$ & High corrosion risk \\
$<1.0$ and $>0.4$ & Medium corrosion risk \\
$<0.4$ & Low corrosion risk \\
\hline
\end{tabular}

Society limits in Table 3; however, they can also provide a chloride-ion concentration profile to determine an apparent chloride diffusion coefficient by linear curve fitting (Poulsen, 1995).

Additionally, a quick observation of the chloride-ion ingress depth can be obtained by spraying $0 \cdot 1 \mathrm{M}$ silver nitrate solution directly onto freshly split concrete, indicated by the formation of a white precipitate (Meck and Sirivivatnanon, 2003). This method only indicates the chloride-ion ingress depth, rather than the change in ion concentration with depth.

\subsection{Concrete resistance to chloride-ion ingress}

The ability of chloride ions to penetrate the concrete cover is a key factor in the service life of structural concrete. In reality, chloride ions can ingress concrete through a combination of transport mechanisms, namely absorption by capillary suction, diffusion and permeation (Tuutti, 1982). Absorption by capillary suction and diffusion are the more dominant mechanisms in aggressive chloride environments and can occur simultaneously when concrete is subject to cyclic wetting/ drying, which is considered the most detrimental process (denoted as XD3 and XS3 exposure conditions) (BSI, 2013). Diffusion is a much slower process as the movement of ions occurs in the pore solution of saturated concrete (Kropp et al., 1995).

The composition of concrete can impact its ability to resist the ingress of chloride ions. The transport of liquids predominantly occurs through the cement matrix and depends on the continuity, tortuosity and radius of the pore structure (Kropp et al., 1995). Cementitious materials also have a chloridebinding capacity, which reduces the free chloride ions in the pore solution of concrete and in turn changes the concentration gradient that drives diffusion (Glass and Buenfeld, 2000). This binding occurs due to adsorption and chemical reactions with constituents of the cement matrix that predominantly leads to the formation of Friedel's salt (calcium chloroaluminate hydrate) (Bertolini et al., 2004; Neville, 2011). The binding capacity can be increased through the use of supplementary cementitious materials (SCMs) such as pulverisedfuel ash (PFA) and/or ground granulated blast-furnace slag (GGBS) due to the generation of additional $\mathrm{C}-\mathrm{S}-\mathrm{H}$ (calcium silicate hydrate) through secondary hydration (Andrade and Bujak, 2013; Bapat, 2013; Dhir et al., 1996, 1997; Dunne et al., 2015; Glass and Buenfeld, 2000; Glass et al., 1997; Lollini et al., 2016; Reddy et al., 2002).

Aggregates also play an important role in the transport of liquids as the water-absorption properties and quality of interfacial transition zones (ITZ) can accelerate or decrease the ingress of fluids (Neville, 2011; Ryu and Monteiro, 2002). This is a particularly important concept when considering the use of CCA to replace NA in concrete as it has been shown that the cement paste adhered to the surface of aggregates can influence the water-absorption effects and reduce the quality of the ITZ (Bravo et al., 2015; Kwan et al., 2012; Lofty and Al-Fayez, 2015; Pedro et al., 2014; Soares et al., 2014). It is hypothesised that this is due to the release of air from CCA as water is absorbed during the early curing process, which creates additional voids in the ITZ (Leite and Monteiro, 2016).

\subsection{Effect of coarse CCA on chloride-ion ingress}

The majority of published research on the effect of coarse CCA on concrete durability (water and chloride-ion ingress) has focused on rapid migration and absorption test methods to determine suitable levels of replacement of NA. The general consensus is that replacement levels above 30\% coarse CCA have a detrimental effect on the transport properties of CEM I concrete, which is commonly attributed to the increased water absorption of the aggregates (Limbachiya et al., 2012; Lofty and Al-Fayez, 2015; Soares et al., 2014; Zega et al., 2014). In contrast, Limbachiya et al. (2000) established that a replacement level of up to $100 \%$ may not have a significant effect on the durability performance of high-strength CEM I concretes, provided the CCA was obtained from high-quality precast concrete sources. Higher replacement levels, up to $100 \%$, have been shown to be suitable when SCMs are also incorporated, particularly in relation to chloride-ion ingress resistance (Berndt, 2009; Kou and Poon, 2013; Lima et al., 2013; Somna et al., 2012). Additionally, Dodds et al. (2017a, 2017b) demonstrated that up to $60 \%$ coarse CCA was a suitable replacement level in CEM III/A structural concrete $(50 \%$ replacement of Portland cement) to achieve a similar, or better, durability performance compared with CEM I control concretes produced with NA, while still achieving the specified characteristic strength.

The quantity of coarse CCA is limited to 30 and $20 \%$ in Eurocodes and UK standards, respectively, for structural concrete (BSI, 2013; BSI, 2015a, 2015b). These limits reduce to $0 \%$ if the structure is likely to be exposed to chloride ions during its service life. These limitations do not therefore reflect the published findings, which suggest the need for revised practice guidance. 
However, there is limited research on the effect of coarse CCA on the risk of corrosion initiation of structural concretes using common, well-established corrosion-monitoring techniques. This study investigated the risk of corrosion initiation, the predicted time to corrosion initiation and the depth of chloride-ion ingress of coarse CCA structural concretes when exposed to aggressive chloride environments. Their compressive strength, surface resistivity, water absorption by capillary action and rapid migration testing have been reported previously (Dodds et al., 2016).

\section{CCA composition}

The CCA was obtained from an aggregate recycling facility in Plymouth, UK. The origin and purpose of the demolished structure(s) were unknown (as is virtually all CCA sold from aggregate recycling plants), so it was difficult to characterise the material. The concrete was crushed to a $40 \mathrm{~mm}$ down product, which was later processed to remove the fines content $(d<4 \mathrm{~mm})$ and larger aggregates $(d>20 \mathrm{~mm})$ to obtain a

Table 4. Laboratory analysis of CCA

\begin{tabular}{lcc}
\hline & $\begin{array}{c}\text { Sample } \\
\text { number }\end{array}$ & $\begin{array}{c}\text { Percent by mass } \\
\text { of dried sample }\end{array}$ \\
\hline Cement content & 1 & 11.1 \\
Alkali content & 2 & 12.8 \\
& 1 & $\begin{array}{c}\text { Potassium oxide }-0.12 \\
\text { Sodium oxide }-0.02\end{array}$ \\
Chloride-ion content & 2 & $\begin{array}{c}\text { Potassium oxide }-0.19 \\
\text { Sodium oxide }-0.03 \\
\end{array}$ \\
& 1 & 0.03 \\
& 2 & 0.02 \\
& 3 & 0.01
\end{tabular}

coarse CCA conforming to 'type A' aggregates suitable for concrete (BSI, 2013).

CCA samples were analysed for cement, alkali and chlorideion contents to BS 1881:124 (BSI, 2015c) and were within acceptable limits unlikely to cause contamination problems in the new concrete (Table 4).

The water absorption and particle density of the CCA were analysed and compared with those of NA (rounded quartzite river gravel) (Table 5). The particle density of the coarse CCA was lower than that of NA for both coarse size gradings tested. The water absorption of coarse CCA at $24 \mathrm{~h}$ was found to be 3-4 times greater than that of the NA, but towards the lower end of the reported range in the literature (between $3.6 \%$ and $11.6 \%$ ), which is indicative of a good-quality source.

\section{Methodology}

The corrosion risk of coarse CCA was assessed for CEM I, CEM II/B-V and CEM III/A concretes when exposed to aggressive chloride environments. Concrete beams (reinforced) and cubes were subject to chloride-ion ingress by cyclic wetting/drying and natural diffusion, respectively. Table 6 details the test methods adopted. Well-established assessment methods were adopted to determine the subsequent corrosion risk of the RC beams, with a sample size to provide a large surface for chloride-ion ponding. The natural diffusion coefficient provides a comparison with the apparent chloride diffusion coefficient. Concrete cubes were exposed as per the European standard (BSI, 2015d).

The concrete was designed using the Building Research Establishment (BRE) mix design method to achieve

Table 5. Water absorption and particle density of aggregates

\begin{tabular}{|c|c|c|c|}
\hline $\begin{array}{l}\text { Aggregate } \\
\text { type/grading }\end{array}$ & $\begin{array}{l}\text { Saturated and surface-dried } \\
\text { particle density: } \mathrm{mg} / \mathrm{m}^{3}\end{array}$ & $\begin{array}{l}\text { Water absorption } \\
\text { (30 min): \% }\end{array}$ & $\begin{array}{c}\text { Water absorption } \\
\text { (24 h): \% }\end{array}$ \\
\hline NA $10-20$ mm & $2 \cdot 59$ & 0.63 & 0.89 \\
\hline NA 4-10 mm & $2 \cdot 57$ & 1.07 & $1 \cdot 15$ \\
\hline NA 0-4 mm (sand) & $2 \cdot 61$ & 0.42 & 0.54 \\
\hline CCA $10-20 \mathrm{~mm}$ & $2 \cdot 47$ & $3 \cdot 13$ & $3 \cdot 67$ \\
\hline CCA 4-10 mm & $2 \cdot 44$ & $4 \cdot 15$ & $4 \cdot 35$ \\
\hline
\end{tabular}

Table 6. Justification of test methods

\begin{tabular}{llll} 
Exposure & Test method & Standard/reference & Sample size \\
\hline $\begin{array}{l}\text { Combined absorption } \\
\text { and diffusion }\end{array}$ & Half-cell potential & CS (2004a); ASTM, (2009) \\
& Surface resistivity & CS (2004a); Aashto (2015) \\
& Apparent chloride diffusion coefficient & Poulsen (1995); BSI (2015c) \\
Chloride-ion penetration depth & Meck and Sirivivatnanon (2003) \\
Niffusion & Natural diffusion coefficient & BSI (2015c); BSI (2015d) & Concrete cubes 100 mm ${ }^{3}$
\end{tabular}


characteristic and target mean strengths of $35 \mathrm{MPa}$ and $49 \mathrm{MPa}$, respectively (BRE, 1997). The constituents of each mix are summarised in Table 7. Additional binder content was added to compensate for the inclusion of the coarse CCA $\left(10 \mathrm{~kg} / \mathrm{m}^{3}\right.$ per $20 \%$ coarse CCA inclusion) and the water content for the CEM II/B-V mixes was reduced following recommendations in the BRE mix design method for crushed aggregates.

The coarse CCA replaced the coarse NA at 20, 40 and $60 \%$ by mass. The mixes were labelled PC (CEM I), FA (CEM II/B-V) and BS (CEM III/A), followed by the numeric CCA content. For example, concrete mix PC60 refers to a CEM I concrete made with $60 \%$ coarse CCA (and 40\% NA).

Two concrete beams $(500 \mathrm{~mm} \times 100 \mathrm{~mm} \times 100 \mathrm{~mm})$ were cast for each mix with a $16 \mathrm{~mm}$ dia. steel reinforcing bar with a top concrete cover of $65 \mathrm{~mm}$ to comply with the durability recommendations for a 50-year design life in XS3 exposure conditions (BSI, 2015a, 2015b). A 4 mm cross-linked polyethylene coated titanium wire was riveted to the steel reinforcement prior to casting and extended above the cast concrete surface. The beams were stripped the next day and moist-cured under a damp hessian cloth for $28 \mathrm{~d}$ before being subjected to $2 \mathrm{~d}$ of ponding (wetting) with $3 \%$ chloride-ion solution, followed by $12 \mathrm{~d}$ of drying in the internal laboratory environment on a cyclic basis. The exposure conditions were chosen to allow sufficient drying of the concrete surface in order to maximise the absorption effects. A ponding area of approximately $38400 \mathrm{~mm}^{2}$ was created using $15 \mathrm{~mm}$ high PVC profiles and a silicone-based sealant (Figure 2). The four vertical sides of the beam were sealed using a bitumen-based waterproofing paint to help promote unidirectional movement of the chloride-ion solution.

Close interval half-cell potential $(50 \mathrm{~mm}$ spacing $)$ readings were recorded on the top face of each beam before exposure to the chloride-ion solution (dry reading) and immediately after removing the chloride-ion solution (wet reading), and an value average was calculated (ASTM, 2009; CS, 2004a). All ponded chlorinated water was removed with a cloth prior to recording the half-cell potential measurements. Surface-resistivity readings

Table 7. Mix design constituents

$\begin{array}{lccc} & \begin{array}{c}\text { PC } \\ \text { (CEM I) }\end{array} & \begin{array}{c}\text { FA (CEM II/ } \\ \text { B-V - 30\%) }\end{array} & \begin{array}{c}\text { BS (CEM III/ } \\ \text { A - 50\%) }\end{array} \\ \text { Water-binder ratio } & 0 \cdot 5 & 0 \cdot 4 & 0.5 \\ \text { Cement: } \mathrm{kg} / \mathrm{m}^{3} & 390 & 307 & 195 \\ \text { PFA: } \mathrm{kg} / \mathrm{m}^{3} & - & 131 & - \\ \text { GGBS: } \mathrm{kg} / \mathrm{m}^{3} & - & - & 195 \\ \text { Water: } \mathrm{kg} / \mathrm{m}^{3} & 195 & 175 & 195 \\ \text { Sand: } \mathrm{kg} / \mathrm{m}^{3} & 653 & 650 & 653 \\ \text { Coarse } 10-20 \mathrm{~mm}: \mathrm{kg} / \mathrm{m}^{3} & 775 & 759 & 775 \\ \text { Coarse 4-10 mm: kg/m } & 387 & 378 & 387 \\ & & & \end{array}$

were also recorded at six locations along the top of the beams, and an average calculated, prior to ponding at approximately 28, 56, 90, 180 and 360 d (Aashto, 2015; CS, 2004a).

After approximately 12 months of cyclic exposure, one beam for each concrete mix that was demonstrating the most likely probability of corrosion initiation (using the criteria in Tables 1 and 2 and identifying areas of anodic activity) was drilled at $10 \mathrm{~mm}$ depth intervals until the steel reinforcement was reached at $65 \mathrm{~mm}$ (20 mm dia. drill bit). The dust samples were subsequently tested for chloride-ion content (BSI, 2015c). A chloride profile was determined and a non-steady-state apparent chloride diffusion coefficient calculated following the linear curve fitting method (Poulsen, 1995). The same beams were then split vertically and analysed visually for signs of corrosion (Figure 3). Chloride-ion penetration depths were measured using the colourimetric technique (Meck and Sirivivatnanon, 2003). The calculated apparent chloride diffusion coefficients were used to predict the time taken to corrosion initiation using the error function solution to Fick's

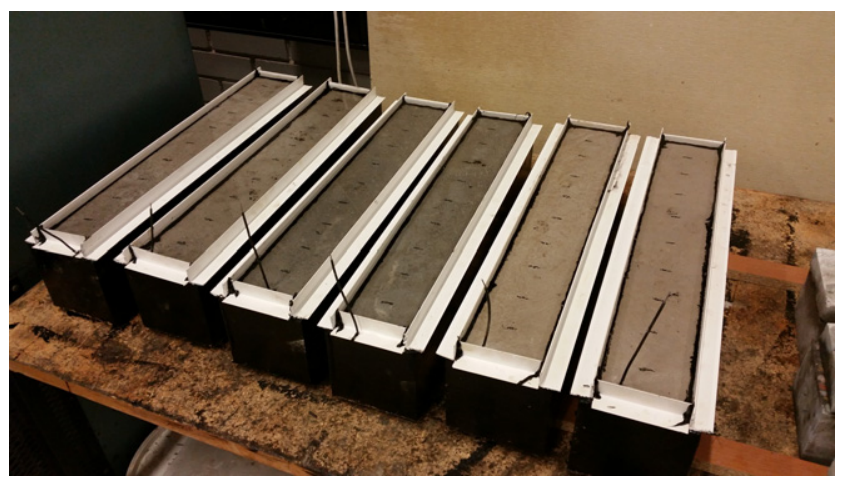

Figure 2. RC beams prepared for cyclic wetting/drying

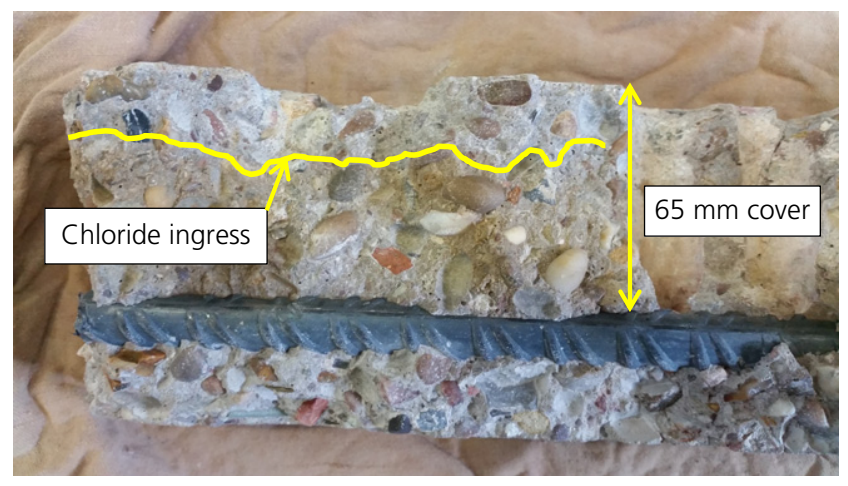

Figure 3. Visual analysis and measurement of chloride-ion ingress, CEM I concrete 


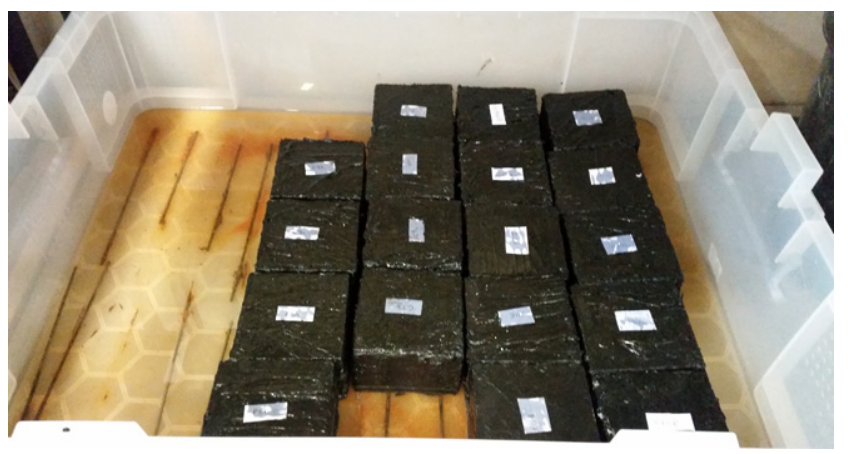

Figure 4. Cubes exposed to chloride-ion solution by the inversion method

second law of diffusion, identified as a chloride-ion concentration of $0.4 \%$ reaching the surface of the steel reinforcement (CS, 2004b). The remaining beams were continually ponded and assessed for corrosion-initiation risk, when exposed to the same cyclic wetting/drying process.

Two concrete cubes $\left(100 \mathrm{~mm}^{3}\right)$ were cast for each mix, and tested for chloride-ion ingress by natural unidirectional diffusion (BSI, 2015d). The cubes were sealed on five faces and exposed to a $3 \%$ sodium chloride $(\mathrm{NaCl})$ solution by the inversion method (Figure 4). Dust samples for chloride-ion analysis were ground from the cube specimens after 3 months exposure in thin layers as detailed in the standard and used to calculate a non-steady-state chloride diffusion coefficient (BSI, 2015c; Poulsen, 1995).

\section{Analysis of results}

As previously stated, the assessment of corrosion risk can be influenced by the ambient $\mathrm{RH}$ and temperature (Angst and Elsener, 2014; Assouli et al., 2008; CS, 2004a; Holmes et al., 2011). All testing was undertaken in a laboratory environment subject to seasonal fluctuations between 18 and $26^{\circ} \mathrm{C}$ and $31-64 \% \mathrm{RH}$, which should be considered as part of the interpretation (Figure 5).

\subsection{Close interval half-cell potentials}

The half-cell potential of the reinforcing steel was recorded bi-weekly, before and immediately following $2 \mathrm{~d}$ of ponding; these are referred to as 'dry' and 'wet' readings, respectively. Surface-saturated concrete is recommended for taking halfcell potentials as it improves the electrical connection between the reference electrode and the steel (CS, 2004a). Therefore, only the 'wet' half-cell potential readings are presented and discussed.

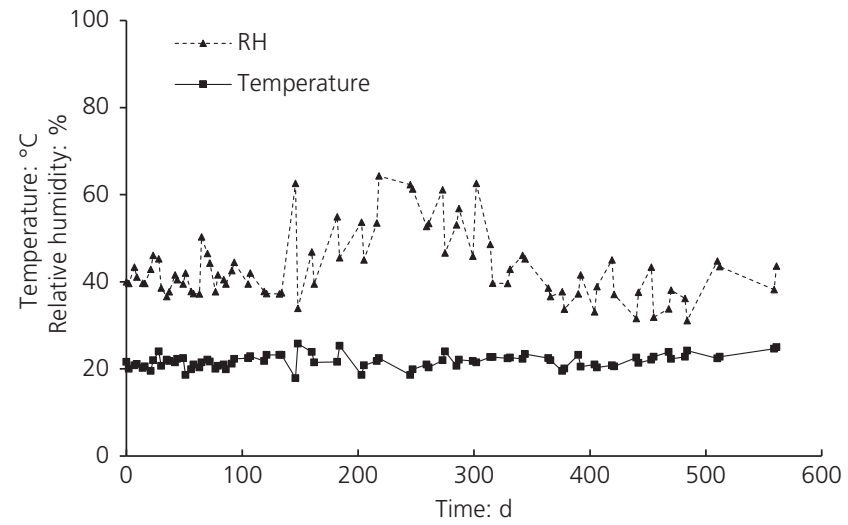

Figure 5. Monitoring of temperature and RH over time

Figures 6-8 show the development of wet half-cell potentials of the reinforcing steel in CEM I, CEM II/B-V and CEM III/A concretes, respectively. Two beams were monitored for each coarse CCA content, denoted as ' $a$ ' and 'b', respectively. The interpretation limits for a low and high probability of corrosion initiation are indicated (ASTM, 2009).

The majority of half-cell potentials remained above the recommended threshold for a low probability of corrosion initiation (less than $-134 \mathrm{mV}$ ), particularly for the CEM I and CEM II/ B-V concretes, even with a coarse CCA content up to $60 \%$. At early ages, the half-cell potentials were more negative and had large variations within the same batch and also across the batch, with no particular trend regarding the coarse CCA content. As time progressed, the half-cell potentials gradually increased in magnitude and became stable. This effect was more exaggerated in the concrete produced with SCMs, most likely due to the delayed hydration process of pozzolanic and latent hydraulic materials (Dhir et al., 1996, 1997; Glass and Buenfeld, 2000; Glass et al., 1997).

Only one beam (PC20a) for the CEM I concrete and two beams (BS20a, BS40b) for the CEM III/A concrete decreased below the threshold for a high probability of corrosion initiation; these, however, quickly returned to the zone of uncertain corrosion activity. These beams, among others, were selected for destructive testing to further investigate probable corrosion initiation after 12 months. The half-cell potentials for all the CEM II/B-V concretes suggested a low risk of corrosion initiation. Overall, no concrete beams showed signs of obvious corrosion initiation in the first 18 months of cyclic ponding and, interestingly, the beams produced with up to $60 \%$ coarse CCA had similar half-cell potentials to those of the control concretes. 


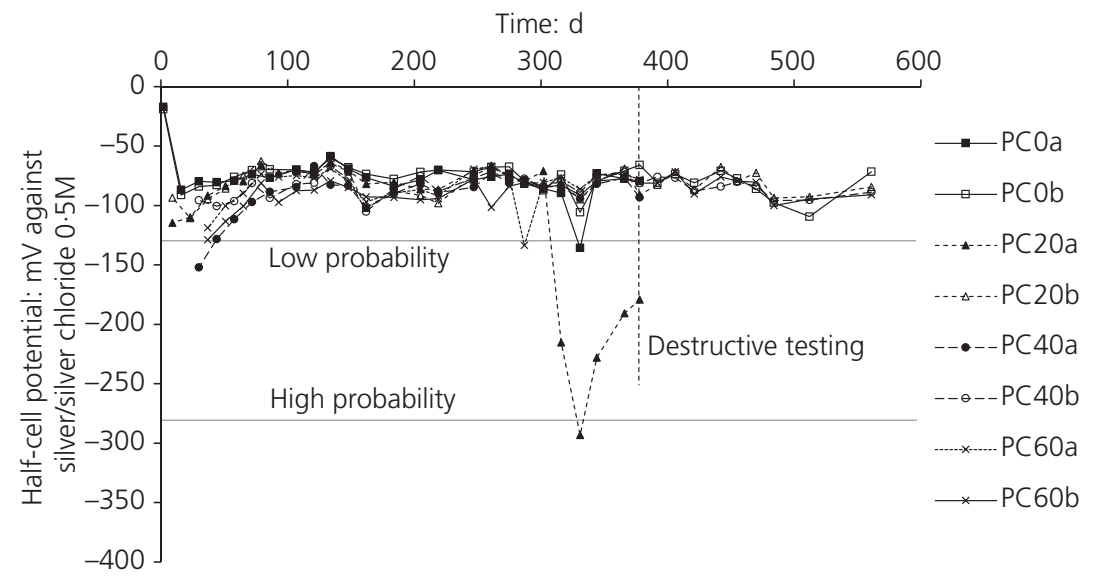

Figure 6. Development of wet half-cell potential over time, CEM I concrete

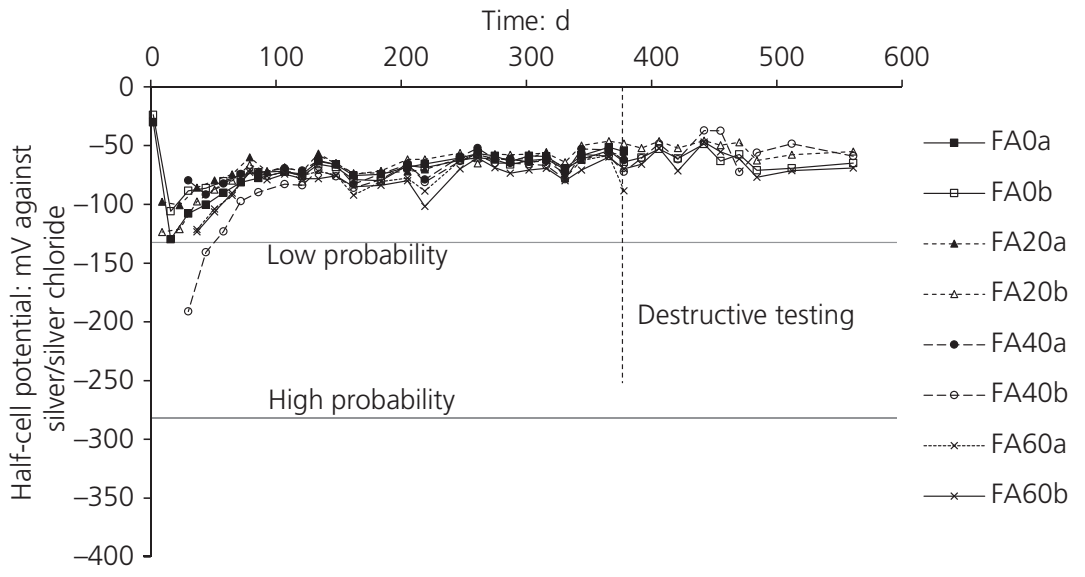

Figure 7. Development of wet half-cell potential over time, CEM II/B-V concrete

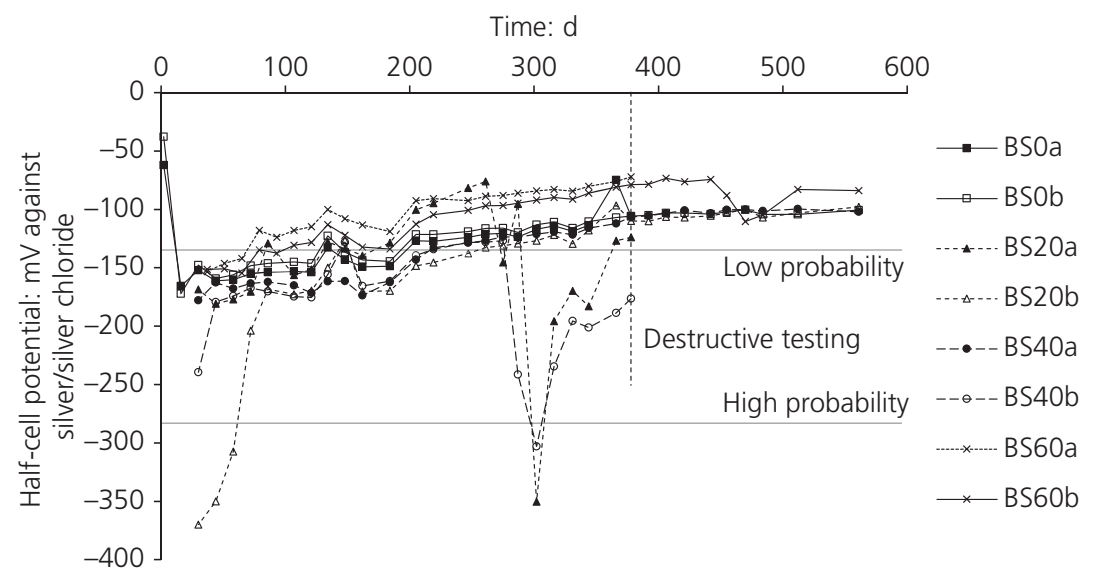

Figure 8. Development of wet half-cell potential over time, CEM III/A concrete 


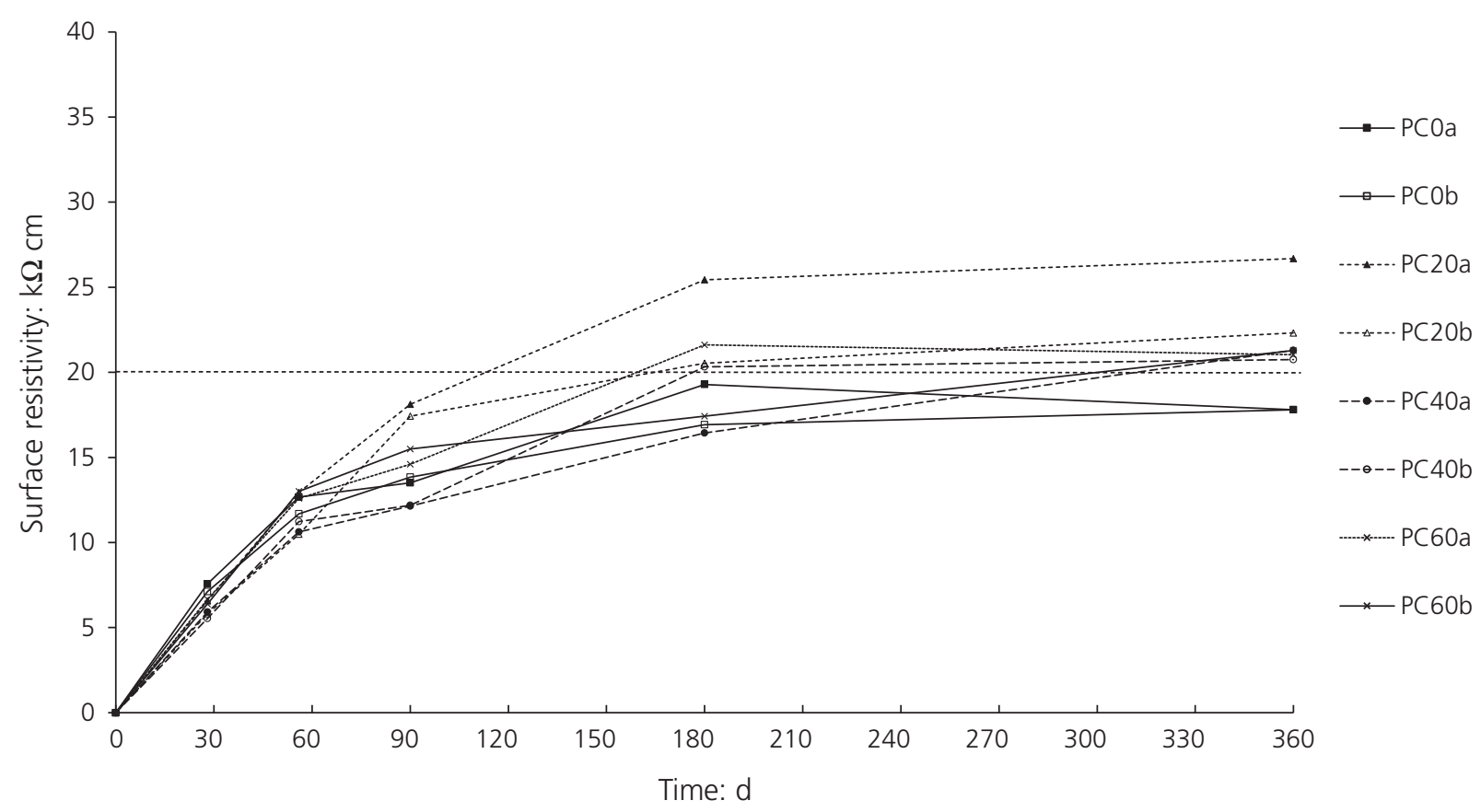

Figure 9. Development of surface resistivity over time, CEM I concrete

\subsection{Surface resistivity}

High levels of moisture can significantly influence surface resistivity readings; therefore, the results were obtained before ponding at approximately 28, 56, 90, 180 and $360 \mathrm{~d}(\mathrm{CS}$, 2004a).

Figures 9-11 show the development of 'dry' surface resistivity of the CEM I, CEM II/B-V and CEM III/A concretes, respectively. The $20 \mathrm{k} \Omega \mathrm{cm}$ limit, which both interpretations (Aashto, 2015; CS, 2004a) acknowledge as a low chloride-ion penetration and corrosion rate, is indicated.

The results clearly show the beneficial effects of SCMs, indicated by the large increase in surface resistivity over time. The surface resistivity of the CEM II/B-V and CEM III/A concretes (even with up to $60 \%$ coarse CCA content) continued to increase over time, with values approximately 3-5 times higher in magnitude than those of the reference CEM I concretes. The majority of CEM II/B-V and CEM III/A concretes achieved the $20 \mathrm{k} \Omega \mathrm{cm}$ threshold for low corrosion rate/ chloride-ion penetration by $56 \mathrm{~d}$. In comparison, the surface resistivity of the CEM I concrete remained much lower, with the majority of results being just above the $20 \mathrm{k} \Omega \mathrm{cm}$ threshold for low corrosion rate/chloride-ion penetration (Aashto, 2015; CS, 2004a). There does not appear to be any evident trend for a higher coarse CCA content having a significant effect on the development of surface resistivity with time.

\subsection{Chloride-ion ingress}

The apparent chloride diffusion coefficient and chloride-ion penetration depth for all concrete types are shown in Figures 12 and 13, respectively. Table 8 shows the predicted time to corrosion using the error function solution to Fick's second law of diffusion, identified by a chloride-ion content of $0 \cdot 4 \%$ reaching the surface of the steel reinforcement.

Analysis of the chloride-ion ingress resistance and the prediction of time to corrosion initiation shows a strong correlation with the observations already presented. The CEM II/B-V and CEM III/A concretes with up to $60 \%$ coarse CCA content outperformed the control CEM I concrete at resisting the ingress of chloride ions when a combination of absorption and diffusion was occurring simultaneously. In both cases, the inclusion of SCMs increased the chloride-ion ingress resistance and increased the predicted time to corrosion initiation to greater than $120+$ years, which is higher than the original 50-year design life of the structural concrete. Additionally, the inclusion of SCMs had a larger influence on the chloride-ion ingress resistance compared with the quantity of coarse CCA, which does not appear to have an evident trend in relation to the chloride-ion ingress.

The natural diffusion coefficients for all concrete types are shown in Figure 14. As with the results of cyclic ponding, the CEM II/B-V and CEM III/A concretes with up to $60 \%$ coarse 


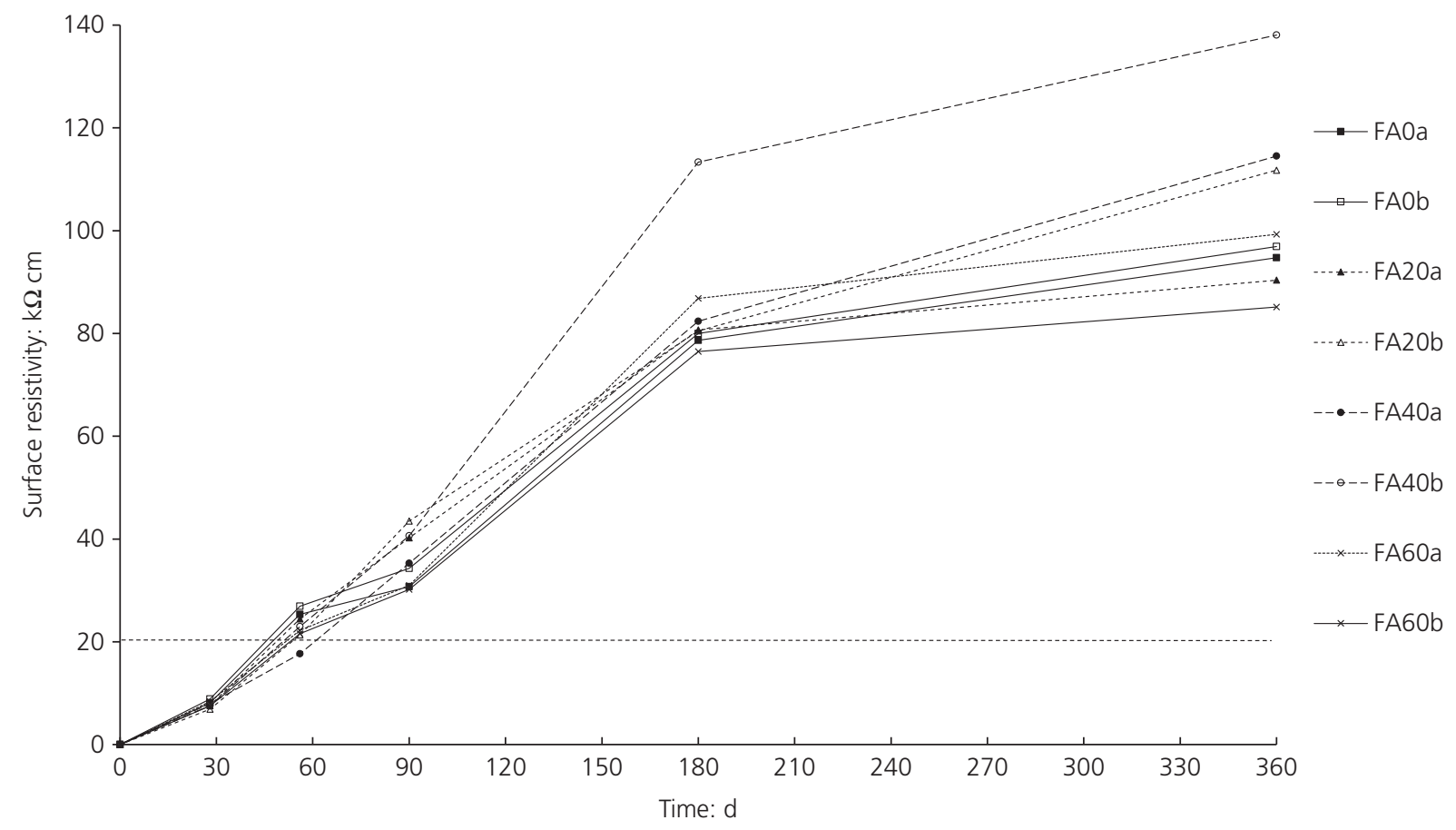

Figure 10. Development of surface resistivity over time, CEM II/B-V concrete

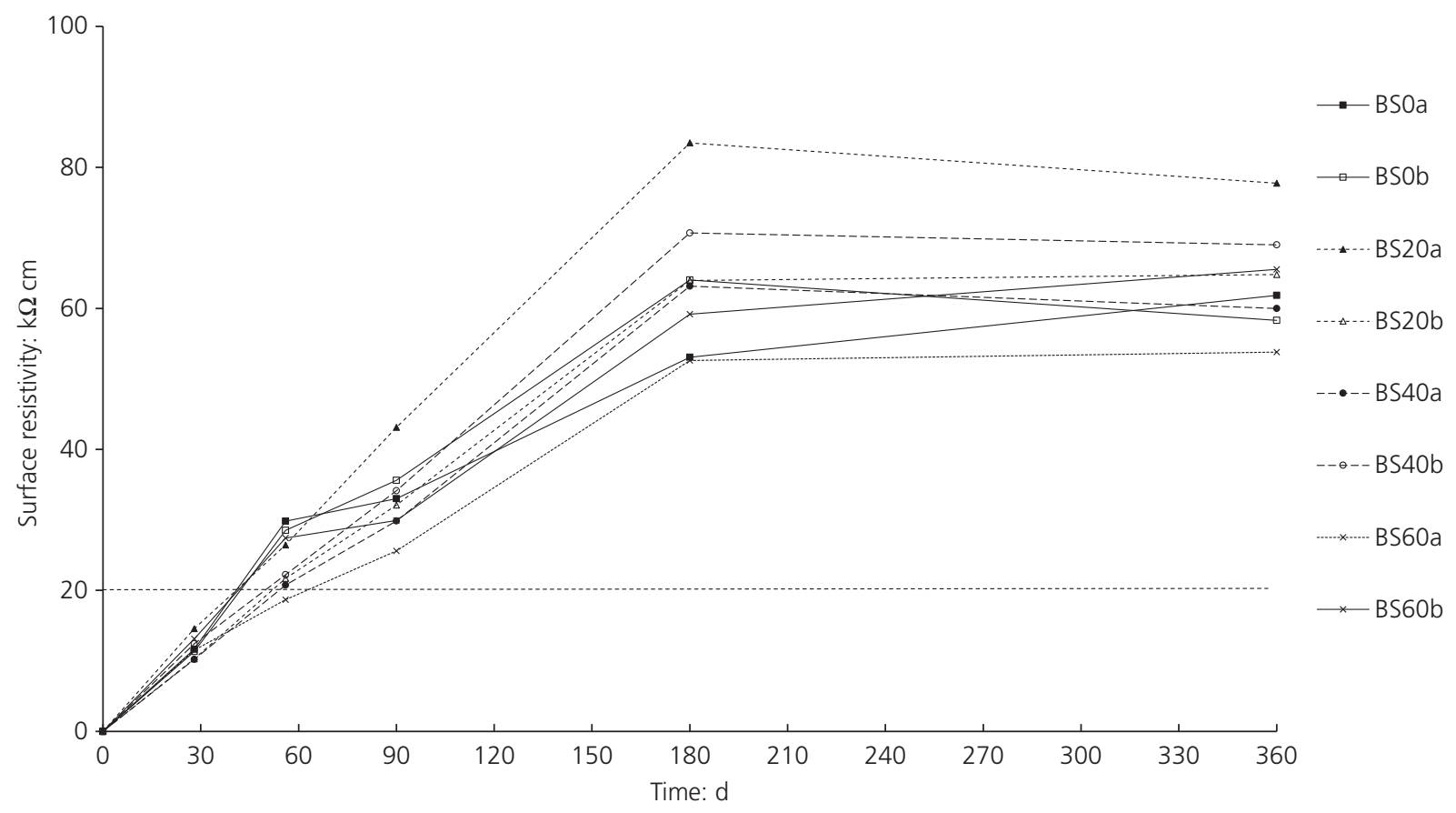

Figure 11. Development of surface resistivity over time, CEM III/A concrete 


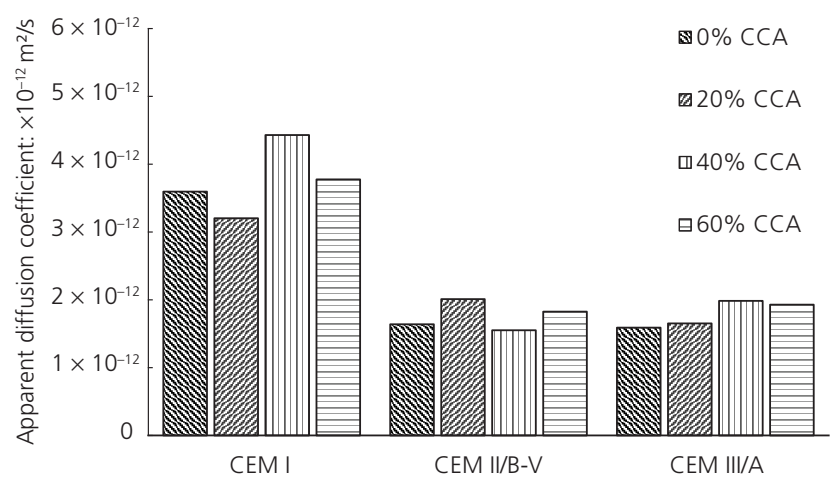

Figure 12. Apparent diffusion coefficient following 12 month exposure to cyclic wetting/drying

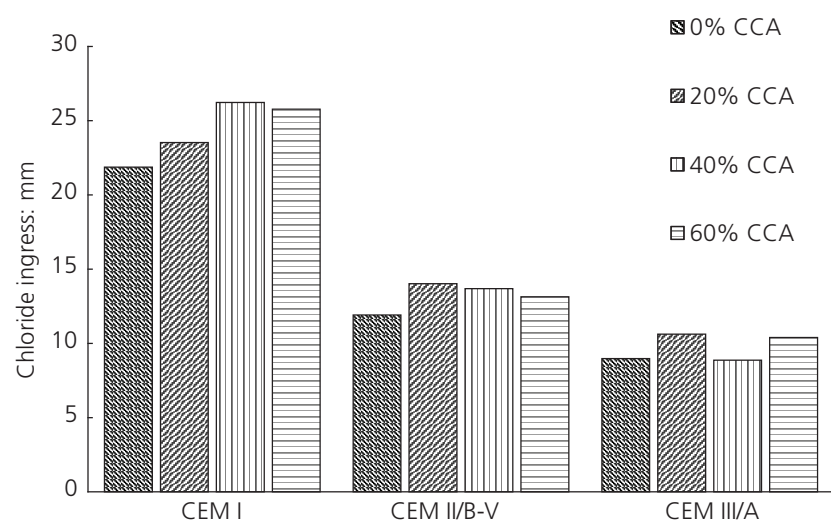

Figure 13. Chloride-ion ingress following 12 month exposure to cyclic wetting/drying

Table 8. Prediction of time to corrosion initiation (years)

\begin{tabular}{lcccc|} 
CCA content: $\%$ & $\mathbf{0}$ & $\mathbf{2 0}$ & $\mathbf{4 0}$ & $\mathbf{6 0}$ \\
\hline CEM I & 39 & 66 & 42 & 47 \\
CEM II/B-V & $120+$ & $120+$ & $120+$ & $120+$ \\
CEM III/A & $120+$ & $120+$ & $120+$ & $120+$ \\
\hline
\end{tabular}

CCA content outperformed the control CEM I concrete at resisting the ingress of chloride ions when diffusion was the only transport mechanism. In this case, there appears to be a more evident trend of decreasing chloride-ion ingress resistance with a higher coarse CCA content.

\section{Discussion}

The effects of coarse CCA on the risk of corrosion initiation, the predicted time to corrosion initiation and the depth of chloride-ion ingress when exposed to aggressive chloride environments were investigated, to encourage the appropriate

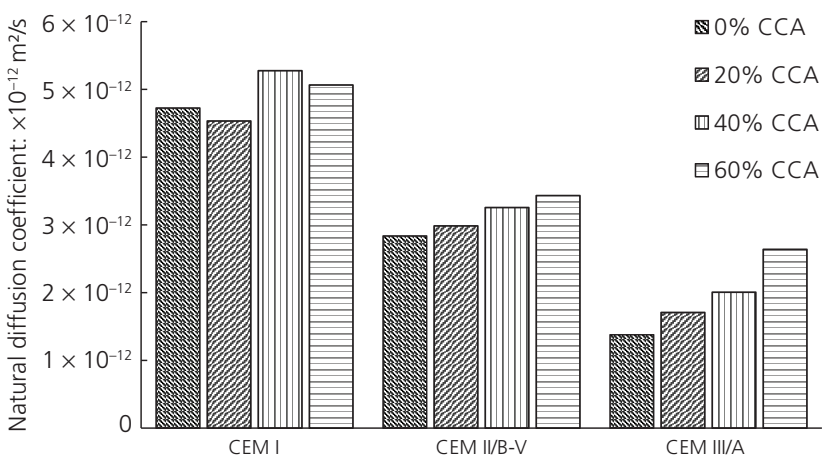

Figure 14. Natural diffusion coefficients following a $90 \mathrm{~d}$ exposure to chloride-ion solution

use of coarse CCA in structural concrete. The majority of close interval half-cell potentials and surface resistivity results indicated a low risk of corrosion initiation for all the concrete types tested. Only three cases of probable corrosion activity were identified throughout the testing period (Figures 6-8), as indicated by a decrease in the half-cell potential below $-284 \mathrm{mV}$ (Figures 6 and 8). The results of destructive testing and measurement of chloride-ion ingress resistance, however, indicated that none had taken place (Figures 12 and 13, Table 8).

For all the test methods, the CEM II/B-V and CEM III/A concretes with up to $60 \%$ coarse CCA outperformed the control CEM I concretes with $100 \%$ NA. These concretes had lower risks of corrosion initiation compared with control CEM I concretes, as indicated by stable half-cell potential readings above the $-134 \mathrm{mV}$ threshold for low corrosion initiation risk, surface-resistivity readings significantly higher than the $20 \mathrm{k} \Omega \mathrm{cm}$ threshold for low chloride-ion penetration/corrosion rate, a higher chloride-ion ingress resistance for all transport mechanisms tested and a higher predicted time to corrosion initiation beyond the design life of the structural concrete adopted for this study. Additionally, the delayed hydration of CEM II/B-V and CEM III/A concretes continued to reduce the risk of corrosion initiation, as indicated by the magnitude of half-cell potentials and surface resistivity readings continuing to increase with time. The inclusion of SCMs also had a larger influence on the chloride-ion ingress resistance compared with the quantity of coarse CCA, which largely outweighed any observed detrimental effects. In the majority of the test methods adopted in this study, there did not appear to be an evident trend of resistance to chloride-ion ingress with increasing coarse CCA content. These findings are in agreement with other published studies on the beneficial effects of SCMs and highlight the advantages of their use in combination with coarse CCAs (Dhir et al., 1996, 1997; Glass and Buenfeld, 2000; Glass et al., 1997). 
Dodds et al. (2017a, 2017b) demonstrated that up to $60 \%$ coarse CCA was a suitable replacement level in CEM III/A structural concrete (at $50 \%$ replacement of Portland cement) in terms of the effect on microstructure, water and chloride-ion ingress and compliance with characteristic cube strength at later ages. The current research used well-established assessment techniques to determine the corrosion risk of CEM I, CEM II/B-V and CEM III/A concretes with coarse CCAs. The results complement the existing research as it has been shown that CEM II/B-V and CEM III/A concretes produced with up to $60 \%$ coarse CCA have a lower risk of corrosion initiation than control CEM I concrete produced with $100 \%$ NA when exposed to aggressive chloride environments. The replacement level of $60 \%$ coarse CCA is double the recommended limit in other published literature and the existing European and British standards - a significant outcome for the wider implementation of coarse CCA in structural concrete (Limbachiya et al., 2012; Lofty and Al-Fayez, 2015; Soares et al., 2014; Zega et al., 2014). The findings presented highlight that the limitations imposed by existing design standards are conservative at best and do not properly reflect the findings of published data.

\section{Conclusions}

Currently, there is limited research on the effect of coarse CCA on the longevity of RC structures exposed to aggressive chloride environments, particularly in relation to corrosion initiation, and hence in this regard the research presented here is unique. Structural concretes with varying quantities of coarse CCA were exposed to aggressive chloride environments. The risk of corrosion initiation was assessed using commonly adopted techniques for RC structures. On the basis of analysis of the results and determining the risk of corrosion initiation from a range of test methods, the following conclusions can be made.

(a) For all test methods adopted, the CEM II/B-V and CEM III/A concretes produced with up to $60 \%$ coarse CCA outperformed the control CEM I concrete produced with $100 \%$ NA, and had a lower risk of corrosion initiation.

(b) Similar published work by the authors has shown that low quantities of coarse CCA $(30 \%)$ can have a detrimental effect on the microstructure, water and chloride-ion ingress and compressive cube strength (Dodds et al., 2017a, 2017b). From the results presented in this paper there did not appear to be an evident trend of resistance to chloride-ion ingress with increasing coarse CCA content. Therefore, further research is required to determine if the same detrimental effect is observed when assessing the corrosion initiation risk over longer periods of monitoring.

(c) Throughout testing, only three cases of probable corrosion activity were identified. The results of destructive testing and the measurement of chloride-ion ingress resistance, however, confirmed that no corrosion had occurred and that the corrosion risk remained low. This highlights the benefit of assessing the corrosion risk using a range of test methods and not solely relying on the results of a half-cell potential survey.

(d) The beneficial pozzolanic and latent hydraulic effects of CEM II/B-V and CEM III/A concretes were apparent from the continual increase in half-cell potential and surface-resistivity readings. This conclusion is further strengthened by the observation of improved resistance to chloride-ion ingress for all transport mechanisms tested and the predicted time to corrosion initiation, which remained well above the 50-year design life of structural concrete adopted for this study. Additionally, the inclusion of SCMs had a larger influence on the chloride-ion ingress resistance compared with the inclusion of coarse CCA, and largely outweighed any observed detrimental effects.

The findings of this study complement the existing research by Dodds et al. (2017a, 2017b) and further highlight that CEM II/B-V and CEM III/A structural coarse CCA concretes can be a viable option for future responsibly sourced projects provided that a reliable and consistent source of coarse CCA can be obtained. This is a significant outcome for the wider implementation of coarse CCA into structural concrete applications and highlights the need for new best practice guidance that allows the specification of coarse CCA in structural concrete.

\section{Acknowledgements}

The authors thank the UK Engineering and Physical Sciences Research Council (grant number EPG037272), Loughborough University's Centre for Innovative and Collaborative Construction Engineering and AECOM for funding this research. The authors also acknowledge Dorton Group Limited for providing the mixed CCA source and Hanson Limited for the cementitious materials.

\section{REFERENCES}

Aashto (American Association of State Highway and Transport Officials) (2015) Aashto T358-15: Standard test method for surface resistivity indication of concretes ability to resist chloride ion penetration. Aashto, Washington, DC, USA.

Alonso MC and Sanchez M (2009) Analysis of the variability of chloride threshold values in the literature. Materials and Corrosion 60(8): 631-637.

Andrade C and Bujak R (2013) Effects of some mineral additions to Portland cement on reinforcement corrosion. Cement and Concrete Research 53: 59-67, https://doi.org/10.1016/j.cemconres. 2013.06.004.

Angst UM and Elsener B (2014) On the applicability of the Wenner method for resistivity measurements of concrete. ACI Materials Journal 111(6): 661-672. 
Angst U, Elsener B, Larsen CK and Vennesland O (2009) Critical chloride content in reinforced concrete - a review. Cement and Concrete Research 39(12): 1122-1138.

Assouli B, Ballivy G and Rivard P (2008) Influence of environmental parameters on application of standard ASTM C876-91: half-cell potential measurements. Corrosion Engineering, Science and Technology 43(1): 93-96.

ASTM (2009) ASTM C876-09: Standard test method for corrosion potentials of uncoated reinforcing steel in concrete. ASTM International, West Conshohocken, PA, USA.

Bapat JD (2013) Mineral Admixtures in Cement and Concrete. CRC Press, Boca Raton, FL, USA.

Barritt J (2015) An overview on recycling and waste in construction. Proceedings of the Institution of Civil Engineers - Construction Materials 169(2): 1-5, https://doi.org/10.1680/coma.15.00006.

Berndt ML (2009) Properties of sustainable concrete containing fly ash, slag and recycled concrete aggregate. Construction and Building Materials 23(7): 2606-2613.

Bertolini L, Elsener B, Pedeferri P and Polder R (2004) Corrosion of Steel in Concrete: Prevention, Diagnosis, Repair. Wiley-VCH, Weinheim, Germany.

Bravo M, de Brito J, Pontes J and Evangelista L (2015) Durability performance of concrete with recycled aggregates from construction and demolition waste plants. Construction and Building Materials 77: 357-369, https://doi.org/10.1016/ j.conbuildmat.2014.12.103.

BRE (Building Research Establishment) (1997) Design of Normal Concrete Mixes, 2nd edn. BRE, Watford, UK.

Broomfield J and Millard S (2002) Measuring concrete resistivity to assess corrosion rates. Concrete 36(2): 37-39.

BSI (2013) BS EN 206-1:2013: Concrete: Specification, performance, production and conformity. BSI, London, UK.

BSI (2015a) BS 8500-1:2015+A1:2016: Concrete - Complementary British Standard to BS EN 206 - Part 1: Method of specifying and guidance for the specifier. BSI, London, UK.

BSI (2015b) BS 8500-2:2015+A1:2016: Concrete - Complementary British Standard to BS EN 206 - Part 2: Specification for constituent materials and concrete. BSI, London, UK.

BSI (2015c) BS 1881-124:2015: Testing concrete - Part 124: Methods for analysis of hardened concrete. BSI, London, UK.

BSI (2015d) BS EN 12390-11:2015: Testing hardened concrete Part 11: Determination of the chloride resistance of concrete, unidirectional diffusion. BSI, London, UK.

Castellote M and Andrade C (2001) RILEM TC 178 -TMC: testing and modelling chloride penetration in concrete. Round-robin test on chloride analysis in concrete - Part II: analysis of water soluble chloride content. Materials and Structures 34(10): 589-598.

Claisse PA (2014) Transport Properties of Concrete - Measurement and Applications. Woodhead Publishing, Cambridge, UK

CS (Concrete Society) (2004a) Concrete Society Technical Report 60: Electrochemical Tests for Reinforcement Corrosion. Cromwell Press Ltd, Camberley, UK.

CS (2004b) Concrete Society Technical Report 61: Enhancing Reinforced Concrete Durability - Guidance on Selecting Measures for Minimising the Risk of Corrosion of Reinforcement in Concrete. Cromwell Press Ltd, Camberley, UK.

Defra (Department for Environment, Food and Rural Affairs) (2015) UK Statistics On Waste - 2010 to 2012. Defra, York, UK. See https://www.cumbria.gov.uk/elibrary/Content/Internet/538/755/ 1929/421459230.pdf (accessed 29/11/2017).

Dhir RK, El-Mohr MAK and Dyer TD (1996) Chloride binding in GGBS concrete. Cement and Concrete Research 26(12): 1767-1773.
Dhir RK, El-Mohr MAK and Dyer TD (1997) Developing chloride-resisting concrete using PFA. Cement and Concrete Research 27: 1633-1639, https://doi.org/10.1016/S0008-8846(97)00146-4.

Dodds W, Goodier C, Christodoulou C et al. (2016) Durability performance of structural concrete made with coarse recycled concrete aggregates. Proceedings of fib Symposium 2016, Performance-based approaches for concrete structures, Cape Town, South Africa. See https://dspace.lboro.ac.uk/2134/23683 (accessed 11/11/2017).

Dodds W, Goodier C, Christodoulou C, Austin S and Dunne D (2017a) Durability performance of sustainable structural concrete: effect of coarse crushed concrete aggregate on microstructure and water ingress. Construction and Building Materials 145: 183-195, https://doi.org/10.1016/j.conbuildmat.2017.03.232.

Dodds W, Goodier C, Christodoulou C, Austin S and Dunne D (2017b) Durability performance of sustainable structural concrete: effect of coarse crushed concrete aggregate on rapid chloride migration and accelerated corrosion. Construction and Building Materials 155: 511-521, https://doi.org/10.1016/j.conbuildmat. 2017.08.073.

Dunne D, Newlands M, Christodoulou C, McKenna P and Goodier Cl (2015) Chloride ingress testing of concrete. Proceedings of the 4th International Conference on Concrete Repair, Rehabilitation and Retrofitting (ICCRRR) (Dehn F, Beushausen HD, Alexander MG and Moyo P (eds)). CRC Press/Balkema, Leiden, the Netherlands. See https://dspace.lboro.ac.uk/dspace-jspui/handle/2134/19520 (accessed 11/11/2017).

Filho RDT, Koenders E, Pepe M et al. (2013) Rio 2016 sustainable construction commitments lead to new developments in recycled aggregate concrete. Proceedings of the Institution of Civil Engineers - Civil Engineering 166(6): 28-35, http://dx.doi.org/ 10.1680/cien.13.00010.

Glass GK and Buenfeld NR (2000) The influence of chloride binding on the chloride induced corrosion risk in reinforced concrete. Corrosion Science 42(2): 329-344.

Glass GK, Hassanein NM and Buenfeld NR (1997) Neural network modelling of chloride binding. Magazine of Concrete Research 49(181): 323-355, http://dx.doi.org/10.1680/macr.1997.49.181.323.

Glass GK, Reddy B and Buenfeld NR (2000) The participation of bound chloride in passive film breakdown on steel in concrete. Corrosion Science 42(11): 2013-2021.

Glass GK, Davison N and Roberts AC (2006) Pit realkalisation and its role in the electrochemical repair of reinforced concrete. Journal of Corrosion Science and Engineering 9, Paper 10.

Glass GK, Reddy B and Clark LA (2007) Making reinforced concrete immune from chloride corrosion. Proceedings of the Institution of Civil Engineers - Construction Materials 160(4): 155-164, https://doi.org/10.1680/coma.2007.160.4.155.

Goodier Cl, Xueting C, Christodoulou C, Dunne D and Yea R (2015) Resistivity and water absorption of concrete. Proceedings of the 4th International Conference on Concrete Repair, Rehabilitation and Retrofitting (ICCRRR) (Dehn F, Beushausen HD, Alexander MG and Moyo P (eds)). CRC Press/Balkema, Leiden, the Netherlands, pp. 227-236. See https://dspace.lboro.ac.uk/dspace-jspui/handle/ 2134/19521 (accessed 11/11/2017).

Hassan KE, Reid JM and Al-Kuwari MS (2016) Recycled aggregates in structural concrete - a Qatar case study. Proceedings of the Institution of Civil Engineers - Construction Materials 169(2): 72-82, http://dx.doi.org/10.1680/coma.15.00017.

Holmes SP, Wilcox GD, Robins PJ, Glass GK and Roberts AC (2011) Responsive behavior of galvanic anodes in concrete and the basis for its utilisation. Corrosion Science 53: 3450-3454, https://doi.org/10.1016/j.corsci.2011.06.026. 
Kou S and Poon C (2013) Long-term mechanical and durability properties of recycled aggregate concrete prepared with the incorporation of fly ash. Cement \& Concrete Composites 37: 12-19, https://doi.org/10.1016/j.cemconcomp.2012.12.011.

Kropp J (1995) Chapter 6: chlorides in concrete. In RILEM Report 12 - Performance Criteria for Concrete Durability (Kropp J and Hilsdorf HK (eds)). E\&FN Spon, London, UK. Kropp J, Hilsdorf HK, Grube H, Andrade C and Nilsson L (1995) Chapter 2: transport mechanisms and definitions. In RILEM Report 12 - Performance Criteria for Concrete Durability (Kropp J and Hilsdorf HK (eds)). E\&FN Spon, London, UK.

Kwan WH, Ramli M, Kam KJ and Sulieman MZ (2012) Influence of the amount of recycled coarse aggregate in concrete design and durability properties. Construction and Building Materials 26(1): 565-573.

Leite MB and Monteiro PJM (2016) Microstructural analysis of recycled concrete using x-ray microtomography. Cement and Concrete Research 81: 38-48, https://doi.org/10.1016/j.cemconres.2015.11.010.

Lima C, Caggiano A, Faella C et al. (2013) Physical properties and mechanical behaviour of concrete made with recycled aggregates and fly ash. Construction and Building Materials 47: 547-559, https://doi.org/10.1016/j.conbuildmat.2013.04.051.

Limbachiya MC, Leelawat T and Dhir RK (2000) Use of recycled concrete aggregate in high strength concrete. Materials and Structures 33: 574-580, https://doi.org/10.1007/BF02480538.

Limbachiya M, Meddah MS and Ouchagour Y (2012) Use of recycled concrete aggregate in fly-ash concrete. Construction and Building Materials 27(1): 439-449.

Lofty A and Al-Fayez M (2015) Performance evaluation of structural concrete using controlled quality coarse and fine recycled concrete aggregate. Cement \& Concrete Composites 61: 36-43, https://doi. org/10.1016/j.cemconcomp.2015.02.009.

Lollini F, Redaelli E and Bertolini L (2016) A study on the applicability of the efficiency factor of supplementary cementitious materials to durability properties. Construction and Building Materials 120: 284-292, https://doi.org/10.1016/j.conbuildmat.2016.05.031.

Meck E and Sirivivatnanon V (2003) Field indicator of chloride penetration depth. Cement and Concrete Research 33(8): 1113-1117.

NACE International (2012) Guide to Corrosion Management of Reinforced Concrete Structures. NACE International, Houston, TX, USA.
Neville AM (2011) Properties of Concrete, 5th edn. Pearson Education, Harlow, UK.

Pedro D, de Brito J and Evangelista L (2014) Influence of the use of recycled concrete aggregates from different sources on structural concrete. Construction and Building Materials 71: 141-151, https://doi.org/10.1016/j.conbuildmat.2014.08.030.

Poulsen E (1995) Chloride Profiles: Analysis and Interpretations of Observations. AEC Laboratory, Vedbaek, Denmark.

Reddy B, Glass GK, Lim PJ and Buenfeld NR (2002) On the corrosion risk presented by chloride bound in concrete. Cement \& Concrete Composites 24(1): 1-5.

Ryu JS and Monteiro PJM (2002) Effect of specific gravity of coarse aggregate on interfacial transition zone, permeability, and strength of concrete. British Ceramic Transactions 101: 30-34, https://doi.org/10.1179/096797801225000806 .

Soares D, de Brito J, Ferreira J and Pacheco J (2014) Use of coarse recycled aggregates from precast concrete rejects: mechanical and durability performance. Construction and Building Materials 71: 263-272, https://doi.org/10.1016/j.conbuildmat. 2014.08.034.

Somna R, Jaturapitakkul C and Amde AM (2012) Effect of ground fly ash and ground baggase ash on the durability of recycled aggregate concrete. Cement \& Concrete Composites 34(7): 848-854.

Tuutti K (1982) Corrosion of Steel in Concrete. Swedish Cement and Concrete Institute (CET), Stockholm, Sweden, no. 4-82.

Wrap (Waste and Resources Action Programme) (2015) Resource Efficiency in Demolition - An Overview of the Demolition Industry's Potential to Improve the Resource Efficiency of Your Regeneration Projects. Wrap, Banbury, UK. See http://www.wrap. org.uk/sites/files/wrap/BM_cs_Demolition_breifing_note. 13b7b4d7.11046.pdf (accessed 15/07/2016).

Yehualaw M and Woldesenbet A (2016) Economic impacts of recycled concrete aggregate for developing nations: a case study in the Ethiopian construction industry. Construction Research Congress 2016: 250-259, https://doi.org/10.1061/ 9780784479827.026.

Zega CJ, Di Maio AA and Zerbino RL (2014) Influence of natural coarse aggregate type on the transport properties of recycled concrete. Journal of Materials in Civil Engineering 26(6): 04014006-1-04014006-9.

\section{How can you contribute?}

To discuss this paper, please email up to 500 words to the editor at journals@ice.org.uk. Your contribution will be forwarded to the author(s) for a reply and, if considered appropriate by the editorial board, it will be published as discussion in a future issue of the journal.

Proceedings journals rely entirely on contributions from the civil engineering profession (and allied disciplines). Information about how to submit your paper online is available at www.icevirtuallibrary.com/page/authors, where you will also find detailed author guidelines. 